\title{
ROSS RIVER VIRUS IN WESTERN SYDNEY: A SEROLOGICAL SURVEY
}

\author{
Lisa Allchin, Helen Ptolemy, George Truman, and \\ Krishna Hort \\ Wentworth Population Health Unit \\ Wentworth Area Health Service
}

Ross River virus is an arbovirus predominately associated with rural Australia, ${ }^{1,2}$ although outbreaks have also occurred on the fringe of metropolitan areas. Periodically, notifications of Ross River virus infection in residents of the Wentworth Area Health Service have been reported, 3,4 with the majority of these cases likely to be acquired locally. Following the notification of cases of Ross River virus infection acquired from one locality in the Wentworth Area Health Service in 1999 and in 2000-01, a serological survey accompanied by a self-administered questionnaire was performed. This article describes the results of the survey and the questionnaire that were undertaken to determine the prevalence of undiagnosed cases and to investigate the prevalence of risk factors.

\section{METHODS}

The serological survey was designed to identify the prevalence of undiagnosed cases within the local area where cases had been previously notified. To accompany the survey, a questionnaire was designed to identify the symptoms and risk factors associated with any further cases notified.

The Werrington neighbourhood, within the Penrith Local Government Area, was chosen as it contained the residence of notified cases of Ross River virus infection. A list of households from an area of approximately three-square kilometres within Werrington was obtained, using an electronic telephone directory. Phone calls were made to every second household on the list, and additional phone calls were made where there was no response. Within the households contacted, all individuals over the age of 12 years were eligible to take part in the survey and invited to attend a clinic for a free blood test. A letter confirming the place and time of the clinic appointment was sent to participating households. Clinics were held twice-weekly at the local community centre over a three-week period during May 2001. At the clinic, each participant provided $10 \mathrm{ml}$ of blood and completed a self-administered questionnaire on risk-avoidance behaviours and symptoms for Ross River virus infection, and for possible exposures to mosquitoes during the period January to May 2001.

Blood samples were tested for specific antibodies against Ross River virus at the Institute of Clinical Pathology and Medical Research, Westmead using a neutralising Enzyme Linked Immunosorbent Assay (ELISA) total antibody test. This test has a sensitivity of 99 per cent and a specificity of 100 per cent. ${ }^{5}$ If the test was positive, specific IgM was measured using an IgM capture ELISA, a test that has a sensitivity of 98 per cent and a specificity of 99 per cent. ${ }^{5}$

A case of Ross River virus infection was defined as a positive serological result, irrespective of symptoms. Where symptoms consistent with Ross River virus infection were reported, local acquisition was defined as not having travelled outside the Penrith Local Government Area during the incubation period (which is four weeks prior to onset of illness). Participants with positive results were contacted by telephone and a letter was sent to participants with negative results.

The data were entered into Microsoft Access and analysed using Excel and SAS software. Ethics approval was granted by the Wentworth Area Health Service Ethics Committee.

\section{RESULTS}

The contact details of 1,345 households were obtained. Of the 778 calls made, 444 (57 per cent) agreed to receive information on Ross River virus infection. Of the 444 households who agreed to receive information, 179 households agreed to participate in the survey. Of these 179 households, 325 residents agreed to attend the clinic, provide blood samples, and answer a self-administered questionnaire.

A comparison between the population of the survey area and the sample population tested for Ross River virus is shown in Table 1.6 The age structure of the sample population was significantly different compared to the study population $\left(\chi^{2}=50.6, d f=7, \mathrm{p}<0.01\right)$ with the older age group (50-75 years of age) over-represented and the

\section{TABLE 1}

ESTIMATED RESIDENTIAL POPULATION AT JUNE 1999 AND SAMPLE CHARACTERISTICS AT MAY 2001, WERRINGTON, NSW

\begin{tabular}{|lcc|}
\hline Variable & $\begin{array}{c}\text { Estimated } \\
\text { residential } \\
\text { population }\end{array}$ & $\begin{array}{c}\text { Sample } \\
\text { characteristics }\end{array}$ \\
\hline $\mathbf{N}$ & $\mathbf{4 7 0 9}$ & $\mathbf{3 2 5}$ \\
Males (\%) & 50.0 & 45.2 \\
Females (\%) & 50.0 & 54.8 \\
Aged $<25$ years (\%) & 29.4 & 17.2 \\
Aged $\geq 25$ and $<50$ years (\%) & 56.1 & 55.1 \\
Aged $\geq 50$ and $<75$ years (\%) & 13.4 & 25.2 \\
Aged $\geq 75$ years (\%) & 1.1 & 2.5 \\
\hline Source: Wentworth Population Health Unit. \\
\hline
\end{tabular}


younger age group ( $<25$ years of age) under-represented in the sample population.

Of the 325 residents tested, five had recent exposure (IgG positive, IgM positive) and six had a previous exposure to Ross River virus (IgG positive, IgM negative). This produced a point prevalence of 1.5 per cent for recent exposure $(95 \% \mathrm{CI}=0.5-3.6)$. Of the five recently exposed cases, three were symptomatic and two were asymptomatic. Two of the symptomatic cases most likely acquired the infection locally as they reported that they had not travelled outside the area during the incubation period. None of the five recent Ross River virus infections had been previously diagnosed or notified to the Wentworth Population Health Unit.

The majority of participants who provided a blood sample did not to take precautions against Ross River virus infection (Table 2). Behaviours were also compared between those aware of the risk of Ross River virus infection from mosquito bites (75.6 per cent of participants) and those unaware of the risk from mosquito bites (24.4 per cent of participants). Those aware of the risk were significantly more likely to remove mosquitobreeding sites than those unaware of the risk (Relative Risk 'RR' $=2.5,95 \% \mathrm{CI}=1.3-5.0$ ). Those aware of the risk were also more likely to use knockdown spray in their bedrooms than those unaware of the risk, although this difference was not significant ('RR' $=1.9,95 \% \mathrm{CI}=0.9-3.7$ ). For the remaining behaviours, there was no significant difference between those aware of the risk and those unaware of the risk.

\section{DISCUSSION}

This survey was undertaken in response to an apparent cluster of Ross River virus infection within the Werrington area. Of three serological surveys for Ross River virus since 1980, one survey in Queensland reported a 1.4-3.5 per cent infection rate, ${ }^{7}$ while studies in New South Wales and South Australia found a recent infection rate of 1.7 per cent and 0 per cent respectively. ${ }^{1,8}$ The prevalence in our study (1.5 per cent) is consistent with these surveys.

Our study is not without limitations, the main one being that only one blood test was taken for each participant and thus seroconversion was not confirmed. Since IgM can persist in the body for some time, it is difficult to determine when infection occurred. ${ }^{9}$ The recruitment process was not random; however, this was not considered to be a problem, as the selection of every second household provided a stratified sample that resulted in participants being drawn from all over the survey area. This method of recruiting individuals to the study was effective, as 325 people from 179 households volunteered to provide a blood sample. This was a reasonable response considering that initial contact was by telephone, and that participants gained little personal benefit from their involvement. Confirming the time and place of blood collection, and the use of the local neighbourhood centre, may have helped increase the response rate. Selection bias could occur, however, with the possibility that individuals with Ross River virus-like symptoms were more likely to agree to provide a blood sample than those without symptoms. Likewise, measurement bias may have occurred, as selfreport was used to record risk behaviours. If this measurement bias did occur, it is likely to have been nondifferential as many risk factors did not differ between those who were aware of the risk of Ross River virus infection and those who were not aware.

The results from the questionnaire of risk behaviours for Ross River virus infection show that the majority of

\section{TABLE 2}

PREVALENCE OF RISK BEHAVIOURS FOR ROSS RIVER VIRUS INFECTION, THOSE AWARE OF RISK FACTORS COMPARED TO THOSE UNAWARE OF RISK FACTORS, WERRINGTON, NSW, MAY 2001

\begin{tabular}{|c|c|c|c|c|}
\hline Precaution & $\begin{array}{l}\text { Percentage of } \\
\text { all participants } \\
\qquad N=295^{c}\end{array}$ & $\begin{array}{c}\text { Percentage of } \\
\text { group aware of } \\
\text { risk of } \\
\text { Ross River virus } \\
n=223\end{array}$ & $\begin{array}{c}\text { Percentage of } \\
\text { group unaware of } \\
\text { risk of } \\
\text { Ross River virus } \\
n=72\end{array}$ & $\begin{array}{c}\text { Prevalence } \\
\text { Rate Ratio } \\
(95 \% \mathrm{Cl})\end{array}$ \\
\hline Use repellent (sometimes or often) & 54.0 & 53.9 & 54.3 & $1.0(0.8-1.3)$ \\
\hline Outdoor activities at home ${ }^{a}$ & 57.3 & 58.7 & 52.8 & $1.1(0.9-1.4)$ \\
\hline Outdoor activities away from home ${ }^{a}$ & 53.2 & 54.7 & 48.6 & $1.1(0.9-1.5)$ \\
\hline Use of repellent inside home ${ }^{a}$ & 8.1 & 6.7 & 12.5 & $0.5(0.2-1.2)$ \\
\hline Use of repellent at work a & 2.4 & 3.1 & 0.0 & b \\
\hline Wear long sleeves and trousers & 20.0 & 19.7 & 20.8 & $0.9(0.6-1.6)$ \\
\hline Remove mosquito breeding sites & 23.7 & 27.8 & 11.1 & $2.5^{*}(1.3-5.0)$ \\
\hline Use knockdown spray in bedroom & 18.3 & 20.6 & 11.1 & $1.9(0.9-3.7)$ \\
\hline Flyscreens on windows and doors & 95.6 & 95.5 & 95.8 & $1.0(0.9-1.1)$ \\
\hline \multicolumn{5}{|c|}{$\begin{array}{l}\text { * }=\text { significant }(p<0.05) \\
a=\text { includes rarely; } \\
b=\text { relative risk cannot be calculated } \\
c=30 \text { of the } 325 \text { participants did not complete the questions relating to risk factors and risk behaviours. } \\
\text { Source: Wentworth Population Health Unit. }\end{array}$} \\
\hline
\end{tabular}


residents did not take precautions against infection whether or not they were aware of the risk. This was despite recent local publicity recommending the use of insect repellent, wearing long-sleeved loose fitting clothing, and removing mosquito-breeding sites to reduce the risk of infection. The lack of precautions taken indicates that the community was unprepared or insufficiently motivated to modify their behaviour to avoid acquiring Ross River virus infection. The only risk behaviour that was different between the two groups-removing mosquito breeding sites-is unlikely to have a significant effect as the nearby open land contains numerous breeding sites for mosquitos such as creeks and swampland. Given the limited potential for environmental modification, public health units in affected areas need to develop innovative ways of influencing risk behaviours within communities at risk.

\section{ACKNOWLEDGEMENTS}

The authors would like to thank the community health nurses who staffed the phones, those who assisted with data collection, the Institute of Clinical Pathology and Medical Research, who participated in the survey, and Dr Kath Weston for assistance in the preparation of this manuscript.

\section{REFERENCES}

1. Hawkes R, Boughton CR, Naim HM, Stallman ND. A major outbreak of epidemic polyarthritis in New South Wales during the summer of 1983-1984. Med J Aust 1985; 143: 330-333.

2. Merianos A, Farland A, Patel M, Currie B, Whelan P, Dentith H, Smith D. A concurrent outbreak of Barmah Forest and
Ross River virus disease in Nhulunbuy, Northern Territory. Commun Dis Intell 1992; 16(6): 110-111.

3. Brokenshire T, Symonds D, Reynolds R, Doggett S, Geary M, Russell R. A cluster of locally-acquired Ross River virus infection in outer-western Sydney. NS W Public Health Bull 2000; 11(7): 132-134.

4. Amin J, Hueston L, Dwyer D, Capon A. Ross River virus infection in the north-west outskirts of the Sydney basin. Comm Dis Intell 1998; 22: 101-102.

5. Institute of Clinical Pathology and Medical Research. Personal Communication (phone call between the ICPMR Arbovirus and Emerging Diseases Unit and the Wentworth Population Health Unit), 2002.

6. Australian Bureau of Statistics. Estimated Residential Populations by Census Collection District for June 1999. CDATA96 Canberra: Commonwealth of Australia, 2000.

7. Aaskov JG, Ross P, Davies CEA, Innes MD, Guard RW, Stallman ND, Tucker M. Epidemic Polyarthritis in Northeastern Australia, 1978-1979. Med J Aust 1981; 2: 1719.

8. Weinstein P, Worswick D, Macintyre A, Cameron S. Human sentinels for arbovirus surveillance and regional risk classification in South Australia. Med J Aust 1994; 160: 494499.

9. Boughton CR, Australian Arboviruses of Medical Importance-A Handbook for General Practictioners and other Clinicians. Melbourne: Royal Australian College of General Practitioners, 1996. \& 